\title{
From the Great Chinese Famine to the Communist
}

\section{Famines}

On Eating Bitterness and the French translation of Mubei

\section{Lucien Bianco}

Translator. Will Thornely

\section{Q OpenEdition}

12 Journals

Electronic version

URL: https://journals.openedition.org/chinaperspectives/6289

DOI: 10.4000/chinaperspectives.6289

ISSN: 1996-4617

\section{Publisher}

Centre d'étude français sur la Chine contemporaine

\section{Printed version}

Date of publication: 1 September 2013

Number of pages: $85-90$

ISSN: 2070-3449

\section{Electronic reference}

Lucien Bianco, "From the Great Chinese Famine to the Communist Famines", China Perspectives [Online], 2013/3 | 2013, Online since 01 September 2013, connection on 05 January 2022. URL: http:// journals.openedition.org/chinaperspectives/6289; DOI: https://doi.org/10.4000/chinaperspectives. 6289 


\title{
From the Great Chinese Famine to
}

\section{the Communist Famines}

\section{On Eating Bitterness and the French translation of Mubei}

\author{
LUCIEN BIANCO
}

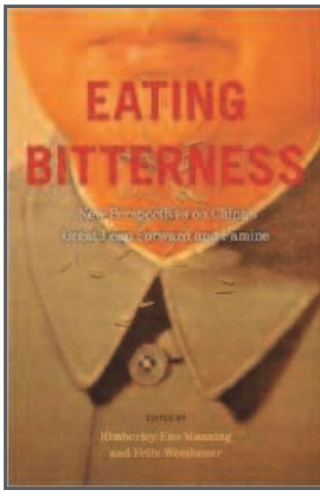

Kimberley Ens Manning and Felix Wemheuer (eds.), Eating Bitterness: New Perspectives on China's Great Leap Forward and Famine, Vancouver, UBC Press, 2011, 321 pp. n 2008, research into the Great Chinese Famine of 1958-1962 entered a decisive new phase. Adopting the direction first taken by Becker, it turned its main focus to the local effects of the famine, the behaviour of officials, and the attempts of the starving to survive. (1) Eating Bitterness, which is the outcome of a collaboration between researchers from the People's Republic of China (PRC), Canada, the United States, and Austria, a number of whom had access to local archives or conducted patient interviews, belongs firmly to this new current, as emphasised, for example, by the excellent introduction by the two editors. Espousing greater prudence than Dikötter, they stand by previous estimates of the total number of deaths resulting from the famine, which range from 15 to 43 million. Unlike him, they do not disregard the demographic and economic context, and they recall (p. 3) the number and scale of famines that hit China between 1876 and 1943.

The first half of the book is confined to historiographical, ideological, and literary discussions. Suzanne Weigelin-Schwiedrzik illustrates how the historiography of the Great Leap has gradually moved away from the orthodox view, the interpretation shifting from that of a "tragedy of good intentions" (Li Rui) to that of the utopia and vices of the political system (Zhang Letian), then to recognition of the contradictory interests of the peasants and the state as highlighted by Gao Wangling, who portrays the famine as a turning point in relations between the two. It is the work of writers (Wang Zhiliang, Yu Hua, Mo Yan, etc.) rather than that of historians, memorialists, and essay writers that revealed the horror of the famine and the "peasant resistance." However, writers in favour with the authorities hastened to raise a "screen of ignorance." As early as January 1959, the inevitable Hao Ran published an edifying short story on love among the rural

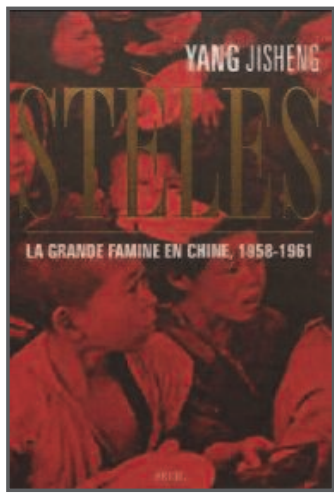

Yang Jisheng,

Stèles. La grande famine en Chine, 1958-1961, French translation by Louis Vincenolles and Sylvie Gentil, Paris, Éditions du Seuil, 2012, 672 pp. [Mubei: Zhongguo liushi niandai dajihuang jishi (Tombstone: A True History of the Great Famine in China in the 1960s), Hong Kong Tiandi tushu, two volumes, 2008, 1096 pp.] blast furnaces, in spite of the fact that he had previously been informed of the ineptitude and lies of the Great Leap. This has been demonstrated by Richard King (p. 66), who has also analysed a more popular and less schematic story, "A Brief Biography of Li Shuangshuang" (by Li Zhun), in which the heroine transforms the revolting food of the canteens into mouth-watering fare. She also accomplishes a hundred other exploits, as glorified in a film made in 1962, but the canteens, which had long since closed, did not feature in the script. (2) The Great Leap Forward gave women activists the opportunity to prove that they carried the same worth as men. As Kimberley Ens Manning has shown, this forced the retreat of a more classical Marxist conception, which favoured sexual equality and showed concern for women's health, and instead favoured Maoist productivism, which resisted the idea of women taking rest at the end of preg-

1. Jasper Becker, Hungry Ghosts: China's secret Famine, London, John Murray, 1996. French translation by Michel Pencréac'h, preface by Jean-Philippe Béja: La grande de famine de Mao, Éditions Dagorno, 1998. Between 1998 and 2008: Cao Shuji, Da jihuang: 1959-1961 nian de Zhongguo renkou (The Great Famine: China's population 1959-1961), Hong Kong, Shidai guoji chuban youxian gongsi, 2005. Since 2008: Ralph A. Thaxton, Catastrophe and Contention in Rural China: Mao's Great Leap Forward Famine and the Origins of Righteous Resistance in Da Fo Village, New York, Cambridge University Press, 2008; Yang Jisheng, Mubei: Zhongguo liushi niandai dajihuang jishi [Tombstone: A True History of the Great Famine in China in the 1960s], Hong Kong, Tiandi tushu, 2 volumes, 2008, 1096 pp. French translation by Louis Vincenolles and Sylvie Gentil, Stèles. La grande famine en Chine, 1958-1961, Éditions du Seuil, 2012, 672 pp.; Qiao Peihua, Xinyang shijian (The Xinyang Incident), Hong Kong, Kaifang chubanshe, 2009; Frank Dikötter, Mao's Great Famine. The history of China's most devastating catastrophe, 1958-62, London, Bloomsbury, 2010; Zhou Xun (ed.), The great famine in China, 1958-1962: A documentary history, Haven, Yale University Press, 2012.

2. Richard King has translated and introduced "A Brief Biography of Li Shuangshuang" and, by way of contrast, another short story that was immediately condemned for its "bourgeois humanism" (or, in other words, realism and sincerity): Heroes of China's Great Leap Forward: Two Stories, Honolulu, University of Hawai'i Press, 2010. 
nancy and after giving birth on the basis that this amounted to a refusal to make the sacrifices required of each person in order to further the revolution. The war on nature was compounded by violence inflicted on the body, as physiological constraints and natural obstacles add up to part of the same battle. Taking this line of thought further, the grain problem was an ideological problem (sixiang wenti), according to the prevailing view in autumn 1957 during the Socialist Education Campaign, the rural embodiment of the Anti-Rightist Campaign. Having a good social background no longer offered protection to a peasant who claimed hunger in an attempt to hand over less grain to the state, or indeed to request assistance; such behaviour was seen to represent a selfish, capitalist attitude and was severely punished in the autumn of 1957. The result of this was that one or two years down the line, when the country was in the grip of famine, nobody dared complain of hunger for fear of being branded anti-socialist. In this respect at least, the measures taken by the Centre proved effective: over the two-year period from 1959 to 1960, the total number of food shortage cases reported to high-ranking officials in the Neibu cankao was lower than that of 1957 alone! In the simple words of Felix Wemheuer, "Discourses can sometimes have deadly consequences" (p. 127).

The following contributions from Chinese researchers bring us to the famine proper. Describing the first eight months of the people's communes (August 1958-April 1959) in Macheng (Hubei), Wang Yanni concludes that the aim of the communes was not so much to impose communism as to mobilise the rural workforce and convert it into a massive industrial army. In Macheng, as in other places cited in Dikötter's account (Chapter 20), a period of frenzied destruction preceded the construction work. Fifty-four thousand houses were demolished in the xian in order to transform the walls into fertilizer and increase the productivity of the workers, who were gathered in one place while also being separated, with men in one dormitory, women in another, and children elsewhere. The more fortunate remained in their own homes, which were not demolished, but they were required to accommodate five more families, meaning 35 people would be squeezed into a house designed for six or seven. Many others were recruited into veritable "armies of production" (pp. 162-163), often spending more time walking to distant places of work than actually working, at a time when there was a shortage of manpower to cultivate the collective fields and feed the blast furnaces. In addition to production, consumption was another issue of such significance that some authors consider the collective canteens to be one of the main causes of the famine. ${ }^{(3)}$ Xin Yi illustrates how the distribution system was continuously evolving in the people's communes as a result of political developments and above all necessity. After two or three months, the initial ideal of free distribution of food, clothes, housing, etc., was wearing thin, and with reserves running out, there was a shift to a mixed system combining distribution "according to need" and a salary proportional to the work performed. Just after the Lushan Conference, the campaign against Right-deviation gave a new boost to the canteens, and by the end of 1959 , they were feeding 400 million people, more than $70 \%$ of the population of the people's communes (and nearly $98 \%$ of those in Henan, one of the provinces worst hit by the famine). The mixed system did not survive the worst of the famine in 1960, when it became necessary to distribute what meagre supplies there were on the basis of work performed, removing the last vestiges of the egalitarianism that had been imposed two years earlier. There was so little to share out that the authorities promoted and sang the praises of food substitutes (daishipin), which are the focus of Gao Hua's contribution. Under the heading "natural substitutes" (plants and animals), pride of place went not to a species of insect, nor to rats or field mice, tree bark, fruit cores, stems, leaves, or roots, but to chlorella, a seaweed that Shanghai started to feed to pigs during the first half of 1960. By the end of July, 27 provinces were growing it to feed their human populations. Diluted in a small amount of urine, it was even more nourishing. At the end of 1960, the Propaganda Department was giving food substitutes a "nutritional value... even greater than that of real grain" (p. 188). The result of this was that many people contracted food poisoning, and some workers grumbled: "This is chicken food, and even chickens wouldn't eat it." Those who felt nostalgic ironically commented: "(Life in the new society) is...not as good as working as a hired-hand for a landlord, ... (it) is certainly nowhere near as good as it was for pigs and dogs back then" (p. 190).

Words were one way of letting off steam, but in order to survive, action was necessary - in particular non-violent action, since the slightest hint of revolt would be met with immediate condemnation by the repressive forces of the regime. As a former zhiqing sent to the countryside, Gao Wangling covered five provinces over a period of nearly a decade spent investigating a thousand-and-one ways of "snatching food from the tiger's mouth" (p. 285). Some required the collusion of officials, for example to conceal a portion of the production, which would then be redistributed among members of the team or, more rarely, the brigade, a practice brought to light by Jean Oi in 1989. (4) The collusion of officials was also necessary for the seven or eight ways in which accounts were falsified (listed on p. 283), but they would have been unaware of the practice of leaving part of the harvest behind in order to retrieve it after nightfall. While major thefts (da tou) remained the exception rather than the rule, instances of small-time theft were common, and around a hundred jin of grain would be diverted from the collective sector in order to keep one's family alive over the course of a year. More substantial thieving took place at night as harvest time approached, the effectiveness of the nocturnal patrols being compromised by the fact that a guard one night could turn thief the next, and vice versa. Gao Wangling does not linger long on a survival strategy that is central to the contribution of Ralph Thaxton, as seen, for example, in the monograph that he dedicates to a village in Henan during and after the famine. ${ }^{(5)}$ This involved surreptitiously eating stillgreen crops (chiqing) off the plants before they grew ripe for harvesting. In Thaxton's view, this survival strategy, which was very widespread in some places (up to $70 \%$ of future harvests were eaten before they reached maturity in seven of the production brigades in Shandong, p. 263), was often the most effective form of peasant resistance, and was responsible for bringing about the end of the famine, an achievement that is usually attributed to the reforming majority of the leading oligarchy once it finally became aware of the scale of the disaster (I share the common opinion). Ralph Thaxton has moved on a great deal since publishing his first book ${ }^{(6)}$

3. This is the view, for example, of Dali Yang's highly accomplished book, Calamity and Reform in China: State, Rural Society, and Institutional Change since the Great Leap Famine, Palo Alto, Stanford University Press, 1996.

4. Jean Oi, State and Peasant in Contemporary China: The Political Economy of Village Government, Berkeley, University of California Press, 1989.

5. This forms the subject matter of Chapter 6 in Catastrophe and Contention in Rural China, op. cit.

6. China Turned Rightside Up: Revolutionary Legitimacy in the Peasant World, New Haven, Yale University Press, 1983. I reviewed this book in the Times Literary Supplement of 30 September 1983. Chen Yung-fa and Gregor Benton wrote a systematic critique of it in Moral Economy and the Chinese Revolution, University of Amsterdam: Anthropological-Sociological Centre, 1986. 
without abandoning the romanticism that makes him magnify the peasant resistance. As a widespread survival strategy during periods of famine, ${ }^{(7)}$ chiqing can extend the life of the pilferer - more so than that of his offspring, since children younger than six years of age cannot digest unripe cereals - before it reduces harvests and rations a few weeks or months later. It was a desperate individual initiative, like so many others at a time when the harshness of the famine meant peasants were less and less able to fight collectively. On the contrary, the famine pushed some to kill and eat their neighbours (or even their own children), and others, in greater numbers, to lynch adolescents guilty of having stolen a handful of rice. Gao Wangling's more guarded and exhaustive contribution makes a list of "acts of opposition" (fanxingwei) without framing them as a resistance movement. If I had had access to this impressive catalogue a decade ago, it would have enabled me to massively expand my description of the "weapons of the weak." That said, I would not have changed my assessment of this litany of "everyday forms of resistance:" (8) Gao paints a familiar picture with an impressive wealth of detail. Thaxton is not the only contributor who can give the impression (Susanne WeigelinSchwiedrzik p. 47, and less distinctly, the editors on pages 14 and 19 of the introduction) of idealising the desperate actions for survival (9) or of revealing the obvious, for example, the conflict between the interests of the peasants and those of a modernising state that was determined, from the outset, to finance "primitive accumulation" at the expense of the exploited peasant majority; so much was recommended by Preobrajenski's model as far back as 1925 .

The regional inequalities that arose during the famine are tackled in two very interesting contributions. First, Jeremy Brown's chapter about Tianjin covers the gulf between town and countryside. People were starving to death in Tianjin by 1961, but it was a paradise compared to the rural xian of the municipality (map, p. 233), which were themselves less afflicted than neighbouring Shandong. The first secretary of the CCP of Tianjin often visited the villages and received daily reports of deaths caused by starvation, attacks on grain stores, and diseases caused by famine. For example, 28,000 peasants were poisoned as a result of eating earth, roots, and other daishipin. Each day, villagers poured in by train, ticketless, with 176,000 arriving illegally during the first quarter of 1960. Some of those who fell to the ground would never stand up again. The city dwellers were quite aware of the fact that many villagers were looting suburban grain warehouses (nine times in three days in one particular locality), while others were taken in and fed by city-dwelling relatives. While the Tianjin authorities were concerned about the fate of the country people, their absolute priority was the survival of the city dwellers. But it went further than that: when it transpired that the city lacked the provisions necessary to celebrate the New Year in 1959, the Grain Director of Tianjin visited Shandong to request assistance. Arriving in Jinan, he came face to face with a Beijing colleague who was visiting on a similar mission. Each left with a cargo of wheat, cabbage, broad beans, onions, and ginger, all supplied by the victims of the famine for their less threatened city-dwelling counterparts. By the end of the following year, the situation was even more strained: Tianjin was down to no more than three days' worth of reserves, forcing the Director of Commerce to inform the central leadership. Only then, with the crisis reaching Tianjin and other large cities, did the Centre take the decision to import grain from Australia and Canada, even though it had been receiving accurate reports of rural deaths caused by the famine for the past year.

\section{$1 \%$ of deaths in Jiangxi, $18 \%$ in Anhui}

It has long been known that the famine struck in a very uneven manner, not only with regard to urban and rural areas, but also in terms of provinces and regions. Those furthest to the north, such as Heilongjiang, Inner Mongolia, Shanxi, and Shaanxi, suffered less than most; conversely, Anhui, Henan, Sichuan, Gansu, and Guizhou were among the worst hit. Theories abound as to what caused these disparities, including the spread of collective canteens, the predominance of agriculture, and the poverty of the province in question (in order to protect city dwellers and workers, the industrial provinces were not required to export as much grain to the other provinces), the level of radicalism of provincial leaders, etc. In what I believe to be the best chapter in the book, Chen Yixin compares the two adjoining provinces of Jiangxi and Anhui, the first of which registered a surplus of 180,000 deaths (1.06\% of its population), the latter $6,330,000$ (18.37\% of the provincial population) between 1958 and 1961. Moreover, Jiangxi took in half a million refugees, mainly from Anhui, most of whom survived. The natural conditions were far more favourable in Jiangxi, which had a lower population density in 1957 of 18.5 million inhabitants over an area of 64,000 sq. mi., compared to the 33.3 million inhabitants of Anhui's 54,000 sq. mi. (one quarter the size of France). Jiangxi also boasted more fertile and better-watered land; $70 \%$ of its farmed area was irrigated by the 1950s, whereas as late as the 1980s, only $40 \%$ of the farmed area of Anhui was similarly provided. In 1949, $150 \mathrm{~kg}$ of grain was being harvested per mu in Jiangxi, compared to $63 \mathrm{~kg}$ in Anhui. Poyang Lake, today a puddle by comparison, was at that time the largest body of fresh water in China, its fish providing nearby inhabitants with the food they needed to survive. Forests, where edible plants and animals could be found, covered $40 \%$ of the area of Jiangxi, as opposed to $12.5 \%$ of Anhui. In the northern part of Anhui, where $49 \%$ of the population was squeezed into $36 \%$ of the province, the disadvantage was even more pronounced, with forests accounting for only $0.1 \%$ of the land. For centuries, Jiangxi had made major tax contributions to the imperial coffers, while Anhui was hardly able to keep its population fed.

Taxation also helps explain the contrast ( $1 \%$ compared to $18 \%$ of deaths caused by famine) that the natural conditions began to reflect. The rate of tax in kind was lower in the old revolutionary bases, which abounded in jiangxi. State farms, which had opened in order to develop wooded hills and mountains, marshes, and swamplands, were exempt from paying tax for one to three years; Jiangxi boasted many such establishments, while they were almost non-existent in Anhui. Figures reflecting the food supply remaining after the payment of tax and compulsory deductions (grain sold to the state at a low price) speak for themselves, showing a drop from 5.2 million tons in 1957 to 4.3 million tons in 1959 in Jiangxi, compared to 7.3 million tons to 4.3 million tons over the same period in Anhui. In 1959, the two provinces

7. An example from another Communist country is provided by the case of North Caucasus in 1933, when many peasants harvested unripe ears to ease their hunger. Nicolas Werth and Alexis Berelowitch, L'État soviétique contre les paysans. Rapports secrets de la police politique (Tcheka, GPU, NKVD) 1918-1939 (The soviet state against the peasant: Secret reports of the political police [Tcheka, GPU, NKVD] 1918-1939), Paris, Tallandier, 2011, p. 540. Zhang Xianliang, who ate a considerable quantity of unripe ears during his captivity, complained that they fermented in the stomach (Grass soup, translated into English by Martha Avery, Minerva, 1995, pp. 187 and 200-01).

8. Chapter 13 of Peasants without the Party: Grass-Roots Movements in Twentieth-Century China, M.E. Sharpe, 2001, and Chapter 18 of Jacqueries et révolution dans la Chine du xxème siècle (Peasants revolts and revolution in 20th-Century China), Paris, Éditions de La Martinière, 2005.

9. Something Frank Dikötter is careful to avoid in Mao's Great Famine. 
therefore had the same amount of grain, but one had 18 million mouths to feed, and the other 33 million.

Finally, and above all, this contrast reflects the unequal zeal exercised by provincial leaders when it came to urging the requisitioning of food and pursuing the various radical projects close to the heart of Mao. The First Secretary of the CP of Anhui, Zeng Xisheng, was friendly with Mao and boasted a revolutionary pedigree (geming zige) far greater than that of the other leaders in the province, whom he showed no hesitation in dismissing. He mobilised large workforces for major projects, as exemplified at the Central Committee Conference of November and December 1958, when he increased by eightfold the volume of stone and earth he would be able to move in the province over the course of a few days. A few months later, more than five million farmers toiling on the irrigation projects were sorely missed in the collective fields, which had been left with only $44 \%$ of the province's agricultural workforce. Unlike the Hunan-born Zeng in Anhui, the four main leaders in Jiangxi were all born in the province, and joined the Soviets of Jiangxi at the end of the 1920s. The first secretary of the provincial $C P$, Yang Shangkui, formed a close-knit team with his lieutenants. At the beginning of 1958, the quartet undertook to increase agricultural production by $80 \%$, an impossible task (Anhui meanwhile promised an increase of $150 \%$ ), but when things took a turn for the worse, they endeavoured to keep the damage to a minimum by transporting rice to regions that were suffering shortages. Zeng never visited the countryside, and turned a deaf ear when his colleagues informed him of the xian hit by the famine. He did order inspections, but only with the purpose of discovering grain hidden away in rural homes. ${ }^{(10)}$ Chen Yixin suggests extending this analysis to other provinces, for example Sichuan, which was blessed with natural resources but led by Li Jingquan, who was, like Zeng, originally from a different province (Jiangxi) to that which he governed so tyrannically.

Two researchers from Hong Kong estimate that the ideology of a provincial leader counted for less than his career-driven calculations. ${ }^{(11)}$ At the time of the Great Leap, provincial first secretaries who were full members of the Central Committee had no more prospects of promotion to look forward to, as the few members of the Political Bureau who had not taken part in the Long March had many years of guerrilla warfare behind them, making them practically irremovable (the Cultural Revolution would change this). Meanwhile, becoming a full member of the Central Committee was a natural ambition for a deputy member. Comparing 24 provinces (excluding Tibet, Xinjiang, and the three municipalities), the authors calculate that deputy members removed and then exported more grain to other provinces and undertook more major projects in irrigation and other areas. They therefore attribute a proportion of the excess mortality to the policies of provincial first secretaries who were deputy members of the Central Committee (although Zeng Xisheng and other radicals were already full members). I am less convinced by the quantitative results obtained by these two authors than by their conclusion that the majority of the provincial leaders who proved their "Maoist" zeal during the Great Leap acted less out of conviction than out of careerism.

\section{Mubei in French}

Eating Bitterness is a substantial new work that approaches the subject from all angles, as is quite often the case in multi-authored books. Even for readers of this journal who already have certain knowledge of the famine, it is no bad thing that the introduction to the book provides a very clear re- minder of anything they may have forgotten, as well as a good many evocative insights. It does not neglect to introduce and praise (p. 13) Yang Jisheng's comprehensive survey, which is the bible in terms of famine during the Great Leap, and in honour of which Xu Youyu wrote a deserved homage in China Perspectives (No. 2009/1, pp. 98-101). The recent French translation, which is cited above, note 1 , condenses the entire first volume of Mubei into five chapters. Four of these (6-9) are dedicated to the provinces that were hit hardest: Henan, Anhui, Sichuan, and Gansu. Chapter 10 provides a brief overview of the famine in various other provinces. The choice is sound, because the uninformed Western reader otherwise runs the risk of becoming bogged down in a repetitive abundance of details with which to measure the scale of the disaster first in one locality or province and then another. This is the inevitable price to be paid for one of the great strengths of the study, by far the most comprehensive ever written about a famine that has long been brushed under the carpet. The less condensed second volume of Mubei is therefore spread over the first five chapters of the French edition and the last six (11-16), which makes it possible to highlight Yang Jisheng's more general considerations, which are damning of Mao and the regime.

I will only mention a few of them here, taken from various points in the book, in particular from the final chapter, which is given over to the impact of the famine on subsequent political development (pp. 591-615 and pp. 659-61 of the French edition, pp. 999-1038 of Mubei, which gives an idea of the respective sizes of the two versions). The famine had barely been brought under control (in 1962) before splits began to appear. Between the "Conference of 7,000," where Liu Shaogi stated the obvious (that the catastrophe was due to human error much more than to nature), and his summoning six months later by Mao - next to his swimming pool! - the gulf began to widen between the two main leaders. When the President of the People's Republic responded to the Party President's accusation that he was painting a black picture by saying: "History will record the role you and I played in the starvation of so many people, and the cannibalism will also be memorialized!", he was perhaps sealing his fate. Mao's reply, "What will happen after I die?", can actually be interpreted both as a reference to the original Soviet revolution ("you intend to knock me down, as Khrushchev did Stalin?") and as a sinister omen of the Cultural Revolution.

Even if Liu Shaoqi's independence - a consequence of the famine, it should be remembered - was to prove fatal to him, it was almost as fainthearted as it was belated, and as late as 1962, he was still publicly getting on Mao's hobby horse. Despite being a victim of the dictator, the fact remains that Liu had reason to fear that History would not absolve him, since the deaths caused by hunger, cannibalism, and so on were also his responsibility and that of the rest of the Party's leaders as well. Nearly all of them behaved like subjugated vassals, from those who exaggerated this with obsequiousness (Zhou Enlai) or sycophancy (Lin Biao) to Chen Yun, one of the very few to have expressed reservations about the Great Leap strategy from the outset. Chen would move himself to the sidelines, if necessary citing poor health, when his lucidity no longer served any purpose, or in other words, when his thinking ran contrary to that of the Great Helmsman. He would then issue the required self-criticism, and if this was considered (by Mao)

10. It should be acknowledged that Zeng Xisheng eventually began to question his unbridled radicalism, to the point where he was one of the initiators of the responsibility contract system that led to his dismissal in 1962.

11. James Kai-sing Kung and Chen Shih, "The tragedy of the Nomenklatura: Career Incentives and Political Radicalism during China's Great Leap Famine," American Political Science Review, Vol. 105, No. 1, 2011, pp. 27-45 
to be unsatisfactory, he would follow it up with lavish praise for the President. My intention is not to criticise Chen in particular (without having experienced the yoke of totalitarianism, there is no way of knowing how one might have behaved in his shoes), but to demonstrate how everyone kept their counsel - or was even approving - in the face of things of which they disapproved. Can we blame them, when the effects of courage have been measured in millions of deaths (Peng Dehuai at Lushan)?

Having dealt with the moral and psychological considerations, ${ }^{(12)}$ we are taken back to the essence of the regime, and not only from the Chinese copy to the Soviet original, but from Stalinist practices to the inexorable development of the Leninist matrix, as predicted by Trotsky and Rosa Luxemburg a year after What is To Be Done was published. This started with the absolute power wielded by Stalin and Mao, sole holders of the truth, or to put it more accurately, the only exegetes authorised with the coded Truth. This led to the boomerang effect caused by the impossible demands of the leaders, which forced local officials to lie or to delay the sending of watereddown reports to the Central Committee for months, to the point that Mao and other leaders could not hope to react until the problems had already become almost intractable. There was also the role of scapegoat that fell to these same officials, working with a Sword of Damocles over their heads and punished either for having balked at applying unsuitable measures, or (later, in 1961-62, when it was no longer possible to deny the extent of the famine) for having executed their orders. Finally, this was a particular style of meritocracy in which conformism and docility were unspoken selection criteria.

\section{Communist famines: China and the USSR}

Taking the relationship between the two "brother" regimes as a pretext, I attempt to draw a succinct comparison between the Chinese and Soviet famines. This does not apply to all the Soviet famines, since those of 192122 and 1946-47 are intertwined with the World Wars which preceded them, and with civil war, typhus, and other epidemics in the case of the former. It is instead restricted to those famines that occurred in times of peace, i.e., in 1958 and 1962 in China and in 1931 and 1933 in the USSR. A first famine killed a good quarter of the population of Kazakhstan in 1931, while the famine that struck the Ukraine, North Caucasus, and southern Russia killed six million people in 1932 and especially in 1933. This is not the world record - that belongs to the Chinese famine - but it was the biggest European famine of the twentieth century. ${ }^{(13)}$ In China and the USSR alike, the same development strategy resulted in excessive transfers from farming to heavy industry. Spurred on by the leader, the strategy increased in pace, with Stalin imposing the Great Break and Mao the Great Leap. The requisition of grain meant peasants went hungry, the nature and operation of the regime transformed these requisitions into ruthless extortion, and the extreme hierarchical organisation prevented any questioning of the ukases of the two dictators. Both in the USSR and in China, the requisitions continued even when the famine had become a recognised fact. However, it was not recognised in the eyes of everyone, for a comparable denial of famine took hold in both countries. For example, Edouard Herriot praised the luxuriance of the Ukrainian kolkhozes he was shown in 1933. In Ukraine, and later China, runaways who were intercepted in stations and on the roads were sent back home. Also in Ukraine, and subsequently China, the famine accelerated suddenly. Its revival in autumn 1959 after the Lushan Conference mirrored the "death blow" (Sokoloff) of summer 1932, although not the final death blow of autumn 1932 and winter 1932-33, when it is possible that Stalin, now seeing the Ukrainian peasants as the main vectors of separatist nationalism, deliberately left them to die or killed them. There was no such intentionality in Mao's decisions, but rather inconsistency and an inability to recognise barely imaginable faults. Ultimately, the speed and adequacy with which assistance was provided to the victims was barely better in China than in the USSR. Also, in both cases city dwellers were favoured over their rural counterparts. While they did not attain the same level of cruelty as Stalin, his Chinese disciples went further than their predecessors when it came to lying, which is no mean feat, judging from Mandelstam's stanzas or the imprecations of Solzhenitsyn. Lying and the corruption of minds - of the Communists and of the guinea pigs themselves - was rampant and uninterrupted all the way from Leningrad (and Warsaw or Prague: see Milosz or Havel) to Guangzhou. The fact remains that the absolute record in terms of yield ever recorded in the history of humanity is held not by the USSR but by China: more than 70 tonnes of rice harvested over $710 \mathrm{~m}^{2}$, or 396 tonnes per acre. ${ }^{(14)}$ If we make an exception of this record attributed to Guangxi, a province that was, after all, well placed in terms of the mortality rates reached between 1958 and 1962, there is a fairly general correlation to be seen between the most barefaced lies and the most numerous deaths from hunger (Anhui, Henan, etc.). There is nothing surprising in this, since claims of outrageous levels of production would justify deadly requisitions.

There are also many other differences, starting with the unusually long duration of the famine in China, compared to Ukraine and North Caucasus, where it was at its worst for no more than five months (from March to July 1933). The real contrast lies in the objective conditions that prevailed in China. Whether in terms of the causes of the famine or the reaction to it, Stalin's responsibility is at least as overwhelming as that of Mao, while that of his accomplices (Molotov or Kaganovitch, for example) was greater than that of Mao's docile lieutenants. Why, then, were the effects of the famine nevertheless more disastrous for China? Part of the reason lies in the fact that in ordinary times (before the famine) China, as an overpopulated country, lived or subsisted closer to limits that were impossible to reduce further: $307 \mathrm{~kg}$ of grain was available per inhabitant in 1956, a record that lasted from the start of the regime until it was equalled and bettered for the first time in 1975 (308 kg), just before Mao's death, which finally opened the

12. On this point, see Jean-Luc Domenach, Mao, sa cour et ses complots. Derrière les Murs rouges (Mao, his court and its plots: Behind the red walls), Paris, Fayard, 2012. The most generous explanation offered by Domenach on these ascetics who had become prosperous, privileged family men, whose families would be doomed to eternal disgrace if they dared confront the supreme power, is that no one wanted to take the risk of causing the fall of the regime that incarnated the dream of their youth and their life's work: "my party right or wrong," or as Trotsky had already and ill-advisedly said: none of us can be right against the Party.

13. Concerning the famine in Kazakhstan, see Isabelle Ohayon, La sédentarisation des Kazakhs dans I'URSS de Staline: Collectivisation et changement social (1928-1945) (The Settlement of the Kazakh in Stalin's USSR: Collectivisation and social change [1928-1945]), Bibliothèque d'Asie Centrale, Paris, Maisonneuve et Larose, 2006. Concerning the famine in the Ukraine, North Caucasus, the southern Volga, western Siberia, and central Russia, reading includes: Alain Blum, Naître, vivre et mourir en URSS (To be born, to live and to die in the USSR), Petite Bibliothèque Payot (original edition: Plon, 1994); R.W. Davies and Stephen Wheatcroft, The years of hunger: Soviet agriculture, 1931-1933, New York, Palgrave Macmillan, 2004; Andrea Graziozi, "Les famines soviétiques de 1931-33 et le Holodomor ukrainien: une nouvelle interprétation est-elle possible et quelles en seraient les conséquences?" (The Soviet Famines of 1931-33 and the Ukrainian Holodomor: Is a new interpretation possible and what would be its consequences?), Cahiers du Monde Russe et Soviétique, Vol. 46, No. 3, 2005, pp. 453-72; Georges Sokoloff, 1933, l'année noire. Témoignages sur la famine en Ukraine (The dark days of 1933: Testimonies on hunger in Ukraine), Paris, Albin Michel, 2000; Viola, Lynne, "La famine de 1932-1933 en Union soviétique" (The Famine of 19321933 in USSR), Vingtième Siècle, No. 88, 2005, pp. 5-22 and Nicolas Werth, "Famines soviétiques, famine ukrainienne" (Soviet Famines, Ukrainian Famines), Le débat, No. 162, 2010, pp. 142-51.

14. Yang Jisheng, Stèles, French version, pp. 443-444. For the footnotes of history, it should be specified that this memorable record was set on 9 September 1958, 18 years to the day before the happiest day in the history of contemporary China, after the fashion of 5 March 1953 for Russia. 
way for crucial agricultural progress. Soviet agriculture was also in urgent need of modernisation, but each Soviet inhabitant could count on an average of $500 \mathrm{~kg}$ of grain annually.

Important though it was, this contrast is no more than a mere difference in degree when compared with the gulf separating these two countries from the privileged West, which leads me in conclusion to put forward two excuses in favour of these regimes that I have quite a bit denigrated. A similar accelerated development strategy triggered the two famines, but development itself was an unavoidable choice for each of these two "backward" countries. The second excuse is much more substantial, and purports that economic backwardness goes hand-in-hand with the barely incipient demographic transition of both continental countries. Starting around 1900 in Russia, and a little later in China, the transition remained in its initial stage, where fertility remained high while mortality quickly dropped. It did so more quickly in China, partly because the fight against infectious diseases had become much more effective the world over by the 1950s than it had been in the 1920s. Apart from the advantage of chronological difference, the effective action taken by the Maoist regime itself had a decisive impact in reducing mortality over the eight years preceding the disastrous Great Leap. Since birth rates did not drop appreciably until the 1970s, natural growth continued at a very swift rate of 2 to $2.5 \%$ annually between 1955 and 1957 during this first phase of demographic transition. The change was slower in the USSR but moved in the same direction, with the birth rate and in particular the death rate clearly higher than in China a generation later, and a slightly slower but nevertheless considerable rate of natural growth in the region of $2 \%$ annually between 1924 and 1928. The essential factor was the reduction in mortality, which was less spectacular than in China (a reduction of approximately $10 \%$ in five years from 1924 to 1928, compared with 27\% in China from 1953 to 1957) but changed twice as quickly as the reduction in birth rates. Although to a lesser degree than in China, this led to an acceleration in population growth and rural overpopulation that was accentuated under the New Economic Policy (NEP). By the time Stalin brought this policy to an end, Russia had 41 million more mouths to feed than at the time of the 1897 census, with a food production system that had barely been improved.

Neither revolutionary state was responsible for a growth in population that was so difficult to manage; to the extent that they were accountable, it is to their credit, for they had contributed to a drop in mortality rates. As long as birth rates failed to track the drop in mortality rates, or in other words, until the demographic transition had progressed sufficiently to institute a period of relative stability, the problem of mouths to feed and the capacity of the agricultural system to rise to this challenge was going to be a delicate issue. This had been the case in China throughout the first decade of the regime, and in the USSR to a lesser degree in the 1920s. It was this precarious foundation that an ill-considered policy caused to shake before giving way to a criminal policy that transformed crisis into catastrophe. The huge personal responsibility of the two dictators, against whom the less stubborn or less cruel national leaders (in the case of China) or regional leaders (in particular in Ukraine) were unable to mount effective resistance, called into question, as already mentioned, the Leninist matrix shared by the two regimes. Though ill-inspired, the power of one imposed itself on all.

\section{Translated by Will Thornely.}

Lucien Bianco is director of studies emeritus at EHESS (School for Advanced Studies in Social Sciences), Paris (biancosud@gmail.com). 